\title{
In vivo effects of thymostimulin treatment on monocyte polarization, dendritic cell clustering and serum p15E-like trans-membrane factors in operable head and neck squamous cell carcinoma patients
}

\begin{abstract}
Head and neck squamous cell carcinoma patients have been characterized by impairments in their cell-mediated immune system, particularly by decreased chemotactic function of monocytes and impairments in the function of the monocyte-derived dendritic cells (viz, a decreased capability to form cell "clusters"). These impairments are thought to be due to immunosuppressive factors of low molecular mass released by tumor, the socalled p15E-like factors. These suppressive effects of p15-like factors can be neutralized in vitro by thymic peptides, such as thymostimulin (TP1). In a randomized double-blind, placebo-controlled multicenter trial in the Netherlands, 41 patients with operable head and neck squamous cell carcinomas (HNSCC) were treated for 10 days prior to surgery with intramuscular TP1 in one of three dosages $(0.5 \mathrm{mg} / \mathrm{kg} ; 1.0 \mathrm{mg} / \mathrm{kg}$ or $2.0 \mathrm{mg} / \mathrm{kg}$ body weight) or treated with placebo. Assessment of monocyte chemotaxis, the capability of dendritic cells to form clusters and the presence of p15E-like low-molecular-mass factors (LMMFs) in serum was performed before TP1 treatment and on the day of surgery. Findings demonstrated that TP1 in a dose of $1.0 \mathrm{mg} / \mathrm{kg}$ and $2.0 \mathrm{mg} / \mathrm{kg}$ resulted in normalization of impaired monocyte chemotactic capability. Although the cluster capability of dendritic cells after TP1 treatment improved, values only reached statistical significance for the $0.5 \mathrm{mg} / \mathrm{kg}$ group. Serum p15E-like LMMF levels were
\end{abstract}

J. D. Kerrebijn (ه)

Department of Otolaryngology Head and Neck Surgery,

University Hospital Dijkzigt, Dr. Molewaterplein 40 ,

3015 GD Rotterdam, The Netherlands

J. D. Kerrebijn - P. J. Simons - H. A. Drexhage

Department of Immunology, Erasmus University,

Rotterdam, The Netherlands

M. Tas

Department of Clinical Oncology, City Hospital,

University of Nottingham, Nottingham, UK

A. J. M. Balm

Department of Otolaryngology Head and Neck Surgery,

The Netherlands Cancer Institute, Amsterdam, The Netherlands not affected by TP1 treatment in any of the patient groups. Contrary to expectations we found no correlation between elevated immunosuppressive LMMFs and defective monocyte chemotaxis or cluster capability of dendritic cells. We conclude that treatment with TP1 can improve monocyte chemotaxis in HNSCC patients but an effect on the production of $\mathrm{p} 15 \mathrm{E}-\mathrm{like}$ factors by carcinoma cells could not be demonstrated.

Key words Head and neck carcinoma - Immunotherapy Monocytes · Dendritic cells - Thymostimulin

\section{Introduction}

Patients with head and neck squamous cell carcinoma (HNSCC) may show certain deficits in their immune functions. The cell-mediated immune system is particularly affected with defects including T-cell function [20, 24, 44], and impaired function of monocytes, monocyte-derived dendritic cells and macrophages [3, 5, 8, 14, 16, 37, 43, 45].

We and others have previously reported in detail impairments of blood monocyte chemotaxis in HNSCC patients. These monocyte chemotactic defects are thought to be caused by factors of low molecular mass (LMMFs, < $25 \mathrm{kDa}$ ) produced by the cancer cells and appearing in the sera of affected patients. These chemotactic defects can be mimicked in vivo in animal models as well as in vitro using healthy donor monocytes exposed to such tumor-isolated LMMFs [4, 36, 38]. Since LMMFs show a structural and functional homology with transmembrane (TM) protein $\mathrm{p} 15 \mathrm{E}$ of animal leukemogenic retroviruses, these substances are therefore generally be referred to as "immunosuppressive p15E-like- or TM-like LMMFs" [9, 38].

The function of monocyte-derived, antigen-presenting dendritic cells is frequently disturbed in the presence of HNSCC. This defect may also be the result of p15E-like LMMFs [43], since such factors in vitro exert a negative effect on the ability of dendritic cells to form cellular clusters. In general, monocyte-derived dendritic cells are class $\Pi$ MHC-positive mononuclear cells with long cytoplas- 
mic extensions that act as excellent accessory cells in immune responses [2, 13, 19, 26, 35].

In an earlier report we demonstrated that abnormal monocyte chemotaxis and a defective cluster capability of dendritic cells could be restored in vitro by the addition of a thymic peptide preparation called thymostimulin (TP1) [43]. Clinical trials investigating the effect of TP1 in various malignant disorders have since been carried out. Tlymphocyte levels were found to increase in patients with malignant melanomas and clinical outcomes could be improved with adjuvant TP1 treatment [7]. In cases with large head and neck cancers overall response to chemotherapy improved if TP1 was used as adjuvant therapy [34], while peripheral T-cell counts improved under the influence of TP1 in patients with Hodgkin's disease [25]. These various observations were the impetus for us to conduct a double-blind, placebo-controlled multicenter study to define in vivo effects of TP1 treatment on monocyte chemotactic functions, cluster capability of dendritic cells and levels of serum p15E-like factors in HNSCC patients.

\section{Patients and methods}

Forty-one patients with operable squamous cell carcinoma of the oral cavity, oropharynx, hypopharynx or larynx agreed to participate in the trial. All patients met the inclusion criteria listed in Table 1 and gave informed consent according to university requirements for human research in The Netherlands. All patients were entered randomly in a double-blind fashion in one of the four following treatment groups: group I - patients receiving placebo treatment; group II - patients receiving $0.5 \mathrm{mg} / \mathrm{kg} \mathrm{TP}$; group III patients receiving $1.0 \mathrm{mg} / \mathrm{kg}$ TP1; group IV - patients receiving $2.0 \mathrm{mg} / \mathrm{kg} \mathrm{TP1}$. To avoid investigator bias, TP1 in different dosages or placebo was (double-blind) injected intramuscularly in each patient once daily for 10 consecutive days prior to definitive operation. All injections were well tolerated and no adverse side effects were seen. Table 2 summarizes the patients' ages and sexes, tumor locations and differentiations, TNM classification and subsequent treatment given. No statistical differences were found for age, TNM classification or tumor differentiations.

Bovine thymic extract (TP1)

Thymostimulin was prepared as a bovine thymic extract using the following procedure described by Bergesi and Falchetti [6] and

Table 1 Inclusion criteria for patients with operable head and neck squamous cell carcinomas (HNSCC) for determining effects of TP1 treatment on monocyte polarization, dendritic cell clustering and serum plsE-like transmembrane factors

- Untreated squamous cell carcinoma of oral cavity, oropharynx, hypopharynx or larynx, with no evidence of metastatic disease

- Curative treatment possible by surgery or surgery combined with radiotherapy

- No other malignancies

- White blood count $>4.10^{9} / 1$; platelets $>100.0^{9} /$ and hematocrit $>30 \%$

- No serious concurrent non-malignant systemic or infectious diseases

- No treatment with corticosteroids
Falchetti et al. [12]. Calf thymus glands were minced and extracted with ammonium acetate. The extract was then heated to $70^{\circ} \mathrm{C}$, filtered, and precipitated with ammonium sulfate. The precipitate was dissolved in water and subjected to ultrafiltration on an Ami-

Table 2 Clinical profiles of patients with HNSCC prior to TP1 treatment ( $W$ well differentiated, $M$ moderately differentiated, $P$ poorly differentiated, $T L$ total laryngectomy, $C R$ composite resection, $P$ pharyngectomy, $P P$ partial pharyngectomy)

\begin{tabular}{lllll}
\hline $\begin{array}{l}\text { Pa- Sex } \\
\text { tients }\end{array}$ & Age & $\begin{array}{l}\text { TNM } \\
\text { classifi- } \\
\text { cation }\end{array}$ & $\begin{array}{l}\text { Local- } \\
\text { ization }\end{array}$ & $\begin{array}{l}\text { Differ- } \\
\text { entia- } \\
\text { tion } \\
\text { grade }\end{array}$ \\
\hline
\end{tabular}

\begin{tabular}{|c|c|c|c|c|c|c|}
\hline \multicolumn{7}{|c|}{ Placebo $(n=9)$} \\
\hline 1 & $q$ & 46 & T1N1M0 & Larynx & M & $\mathrm{TL}$ \\
\hline 2 & $q$ & 51 & T3NOMO & oropharynx & $P$ & $\mathrm{CR}$ \\
\hline 3 & $\delta$ & 67 & T3N1M0 & oral cavity & W & CR \\
\hline 4 & $\hat{0}$ & 59 & $\mathrm{~T} 4 \mathrm{~N} 2 \mathrm{MO}$ & hypopharnyx & P-M & $\mathrm{TL}+\mathrm{P}$ \\
\hline 5 & $\hat{\partial}$ & 45 & T2N1M0 & oropharynx & M & $\mathrm{CR}$ \\
\hline 6 & $\hat{0}$ & 65 & T4N2bM0 & oral cavity & M & $\mathrm{CR}$ \\
\hline 7 & $\hat{o}$ & 67 & T4NOMO & oral cavity & $\mathrm{P}$ & CR \\
\hline 8 & $\delta$ & 45 & T3N2MO & oropharynx & W & $\mathrm{CR}$ \\
\hline 9 & $\hat{0}$ & 60 & T3N2MO & oral cavity & $\mathrm{P}$ & $\mathrm{CR}$ \\
\hline
\end{tabular}

$0.5 \mathrm{mg} / \mathrm{kg}$ TP1 $(n=10)$

$\begin{array}{lllllll}10 & \uparrow & 62 & \text { T4N0M0 } & \text { Oral cavity } & \text { M } & \text { CR } \\ 11 & \uparrow & 61 & \text { T2N0M0 } & \text { oropharynx } & \text { M } & \text { CR } \\ 12 & \delta & 46 & \text { T2N0M0 } & \text { oral cavity } & \text { P-M } & \text { CR } \\ 13 & \delta & 56 & \text { T2N0M0 } & \text { oral cavity } & \text { P } & \text { CR } \\ 14 & \delta & 68 & \text { T1N2cM0 } & \text { larynx } & \text { M } & \text { TL } \\ 15 & \delta & 72 & \text { T2N0M0 } & \text { oral cavity } & \text { W } & \text { CR } \\ 16 & \delta & 52 & \text { T3N0M0 } & \text { oropharynx } & \text { W } & \text { CR } \\ 17 & \delta & 44 & \text { T2N0M0 } & \text { oral cavity } & \text { P } & \text { CR } \\ 18 & \delta & 60 & \text { T2N2aM0 } & \text { oropharynx } & \text { P } & \text { CR } \\ 19 & \text { क } & 74 & \text { T2N1M0 } & \text { oral cavity } & \text { W } & \text { CR }\end{array}$

$1.0 \mathrm{mg} / \mathrm{kg} \mathrm{TP} 1(n=13)$

\begin{tabular}{|c|c|c|c|c|c|}
\hline \multirow{2}{*}{\multicolumn{6}{|c|}{ Oronharynx }} \\
\hline & 61 & T3N1M0 & Oropharynx & $\mathbf{M}$ & CR \\
\hline 21 & 45 & T2NOMO & oral cavity & M & CR \\
\hline 22 & 70 & $\mathrm{~T} 3 \mathrm{~N} 2 \mathrm{M} 0$ & oropharynx & M & CR \\
\hline 23 & 47 & $\mathrm{~T} 2 \mathrm{~N} 2 \mathrm{aM0}$ & hypopharynx & M & $\mathrm{TL}+\mathrm{PP}$ \\
\hline 24 & 56 & T4N2M0 & larynx & M & TL \\
\hline 25 & 78 & T1NOM0 & oral cavity & W & CR \\
\hline q & 65 & T3N2bM0 & oral cavity & M & CR \\
\hline 27 & 44 & $\mathrm{~T} 2 \mathrm{~N} 1 \mathrm{M} 0$ & oral cavity & M & $\mathrm{CR}$ \\
\hline$q$ & 52 & T3NOMO & oropharynx & W & CR \\
\hline$\sigma$ & 66 & T4N1M0 & oropharynx & W & $\mathrm{CR}$ \\
\hline$\delta^{\pi}$ & 56 & T3N1M0 & larynx & M & TL \\
\hline 31 & 64 & T4N1M0 & larynx & $\mathrm{P}$ & $\mathrm{TL}$ \\
\hline 32 & 50 & $\mathrm{~T} 4 \mathrm{~N} 2 \mathrm{M0}$ & hypopharynx & $\mathrm{P}$ & $\mathrm{TL}+\mathrm{PP}$ \\
\hline \multicolumn{6}{|c|}{$2.0 \mathrm{mg} / \mathrm{kg}$ TP $1(n=9)$} \\
\hline 33 & 67 & T4N0M0 & Oral cavity & M & $\mathrm{CR}$ \\
\hline 34 & 58 & T2N2bM0 & oropharynx & $\mathbf{M}$ & $\mathrm{CR}$ \\
\hline$\sigma^{\pi}$ & 59 & T3NOMO & oropharynx & W & CR \\
\hline$\hat{\sigma}$ & 72 & T3N2bM0 & oropharynx & $M-W$ & $\mathrm{CR}$ \\
\hline q & 61 & T2NOMO & oral cavity & M & CR \\
\hline$\sigma$ & 51 & T3N2cM0 & larynx & $M-W$ & $\mathrm{TL}$ \\
\hline$\sigma^{\sigma}$ & 51 & T4N2M0 & oral cavity & M-P & CR \\
\hline 40 & 49 & T3N2bM0 & oropharynx & $\mathrm{P}$ & CR \\
\hline 41 & 37 & T2NOMO & oral cavity & W & $\mathrm{CR}$ \\
\hline
\end{tabular}


con PM-10 membrane. The filtrate was desalted on Sephadex G25 and gel-filtered on Sephadex G-50. Fractions showing characteristic bands at RF 0.22 and 0.24 on polyacrylamide gel electrophoresis were combined and termed "thymostimulin" (TP1). This extract was next lyophilized and its activity expressed as units of T-cell-rosette formation per milligram of protein. No endotoxin was contained in this extract, as tested in doses up to $100 \mathrm{mg} / \mathrm{kg}$ when administered to mice for 21 days or rats for 31 days, or when given to cats or dogs for 180 days in doses up to $50 \mathrm{mg} / \mathrm{kg}$ [12]. Additionally, the extract failed to alter neuromuscular transmission in vitro or in vivo [6].

\section{Isolation of peripheral blood monocytes}

Peripheral blood mononuclear cells from patients and healthy controls were isolated by Ficoll-Isopaque density gradient centrifugation. Cells were washed twice in phosphate buffered saline (PBS) at $\mathrm{pH} 7.4$, containing $0.5 \%$ bovine serum albumin (BSA). Cells were then counted in suspension employing positive staining with non-specific esterase (NSE) as described by Mullink et al. [29]. Monocytes in the Ficoll-Isopaque isolated fraction were enriched by Percoll gradient centrifugation [31]. After washing, the Ficollisolated cell pellet containing both monocytes and lymphocytes was resuspended in RPMI 1640 supplemented with $10 \%$ fetal calf serum (GIBCO, Breda, The Netherlands), $2 \mathrm{~m} M$ glutamine and antibiotics (penicillin and streptomycin), and carefully underlaid with an equal volume of Percoll 1.063 (Pharmacia, Uppsala, Sweden). After centrifugation at $400 \mathrm{~g}$ for $40 \mathrm{~min}$, all cells were collected from the interface, washed twice in medium for $10 \mathrm{~min}$ and counted. This latter suspension now contained 70-95\% NSE-positive cells. This suspension was used for direct monocyte polarization and maturation to obtain dendritic cells (see below).

\section{Formation of dendritic cells}

Dendritic cells were prepared from blood monocytes according to the method described by Kabel et al. [21]. Metrizamide (Serva, Heidelberg, Germany) was dissolved in RPMI supplemented with $10 \%$ fetal calf serum. Cells from the isolated monocyte fractions were exposed to $14.5 \%$ metrizamide in suspension culture for 30 min (using $5 \% \mathrm{CO}_{2}$ at $37^{\circ} \mathrm{C}$ and $100 \%$ humidity). Thereafter, cells were washed by slowly adding culture fluid to prevent osmotic lysis. Cells were then further cultured under non-adhering conditions for $16 \mathrm{~h}$ in polypropylene tubes (with $5 \% \mathrm{CO}_{2}$ and $100 \%$ humidity at $37^{\circ} \mathrm{C}$ ). This procedure yielded $40-80 \%$ cells with a dendritic morphology, showing class II MHC positivity, decreased expression of the monocytic CD14 determinant, decreased phagocytic capability, but enhanced stimulator capability in the mixed leukocyte reaction (MLR). The full technical details of this method are described by Kabel et al. [21] and in Mooy et al. [28].

\section{Clustering of dendritic cells}

The cluster assay as described by Austyn et al. [2] was performed with modifications used by Kabel et al. [21]. Approximately $5 \times$ $10^{4}$ dendritic cells prepared from peripheral blood monocytes were exposed to metrizamide and allowed to cluster for $4 \mathrm{~h}$ in $5 \% \mathrm{CO}_{2}$ at $37^{\circ} \mathrm{C}$ in $250 \mu \mathrm{l}$ flat-bottomed wells. Formed clusters were counted using an inverted microscope and values were expressed as the number of clusters per 6 microscopic fields $(\times 200)$. A cluster was defined as an accumulation of 4-25 cells in three-dimensional configuration. An insufficient amount of blood was received to obtain enough dendritic cells for the cluster assay in 8 cases.

\section{Monocyte polarization assay}

The Cianciolo and Snyderman [10] assay for monocyte polarization was performed with slight modifications [38] to rapidly test monocyte chemotaxis. Outcomes of the assay previously proved to correlate well with outcomes of the conventional Boyden chamber assay to measure chemotaxis to casein [38]. Repeat $0.2 \mathrm{ml}$ aliquots of the Percoll or elutriator purified cell suspension containing $0.2 \times 10^{6}$ monocytes were added to $12-75 \mathrm{~mm}$ polypropylene tubes (Falcon Labware Division, Becton Dickinson, Oxford, Calif., USA) containing $0.05 \mathrm{ml}$ of either medium or formylmethionylleucylphenylalanine (fMLP) in medium, to reach a final concentration of $10 \mathrm{nM}$. All experiments were carried out in duplicate. Tubes were incubated in a waterbath at $37^{\circ} \mathrm{C}$ for $15 \mathrm{~min}$. Incubation was stopped by addition of $0.25-\mathrm{ml}$ ice-cold $10 \%$ formaldehyde in 0.05 $M$ PBS (pH 7.2). Cell suspensions were kept at $4^{\circ} \mathrm{C}$ until counted in a hemocytometer under a light microscope (magnification, $x$ 250 ). Each test was read "blindly" by two persons and 200 cells were counted from each tube. A cell was considered to be "polarized" if one of the following occurred: elongated or triangular shapes, broadened lamellipodia or membrane ruffling.

Chemotactic responsiveness of a monocyte population was expressed as the percentage of polarized monocytes in the presence of fMLP minus the percentage of polarized monocytes in the absence of fMLP. The percentage of polarized monocytes was calculated as follows:

$\frac{\% \text { total cells polarized }}{\% \text { NSE-positive cells }} \times 100 \%$

Lymphocytes were excluded by their lack of any polarization activity in this assay [9].

Determination of p15E-like immunosuppressive factors in patients' sera

Sera for immunological evaluation was collected by venipuncture prior to the first injection of TP1 and $1-2 \mathrm{~h}$ before surgery. In a number of events insufficient sera were received due to Iogistical problems. Sera of healthy hospital staff members served as control sera during all tests. Sera were diluted $1: 1$ in saline and subjected to ultrafiltration through Amicon CD25 Centriflo cones (Amicon Corp., Danvers, Maine, USA) for $15 \mathrm{~min}$ at $800 \mathrm{~g}$ (molecular mass "cut-off point", $25 \mathrm{kDa}$ ). Residues were resuspended and stored at $-20^{\circ} \mathrm{C}$ until further use.

The capability of serum fractions to inhibit fMLP-induced polarization of healthy donor (elutriator-purified) monocytes was determined by incubating $\left(1 \times 10^{6} / \mathrm{ml}\right)$ healthy donor monocytes for $15 \mathrm{~min}$ at $37^{\circ} \mathrm{C}$ either with fMLP alone or with fMLP in combination with a serum fraction (final dilution, $1: 60$ ). Details of the technique have been described by Tas et al. [43]. The percentage of inhibition was calculated as follows:

$i=(1-(\mathrm{Ff}-\mathrm{fo} / \mathrm{Mf}-\mathrm{fo})) \times 100 \%$, where $\mathrm{Ff}=\%$ monocytes polarized after incubation with $\mathrm{FMLP}$ and LMMF; $\mathrm{Mf}=\%$ monocytes polarized after incubation with fMLP alone; and fo $=\%$ spontaneously polarized monocytes.

Spontaneous polarization was not affected by addition of serum fractions to non-fMLP stimulated donor monocytes.

To validate the p15E-like character of LMMF adsorption, experiments were carried out by neutralizing serum fractions at $4^{\circ} \mathrm{C}$ for $16 \mathrm{~h}$ before testing effects on monocyte polarization by using a combination of two p15E-specific mAbs (4F5 and 19F8 as anti$\mathrm{p} 15 \mathrm{E}$ isotypes $\operatorname{IgG} 2 \mathrm{a}$ and $\operatorname{IgG} 2 \mathrm{~b}$ ). The final $\mathrm{mAb}$ dilution was 1 : 200 and final IgG concentration $50 \mu \mathrm{g} / \mathrm{ml}$. Following neutralization, Amicon ultrafiltration was performed to remove complexes. The adsorption/neutralizing procedure was carried out twice. As control antibodies irrelevant anti-human IgG2a and IgG2b were used.

Statistical analysis

Statistical analysis was performed using the Wilcoxon signed rank test; $P<0.05$ was taken as the level of significance. 
Fig. 1 Serum p15E-like lowmolecular-mass factor (LMMF) levels and monocyte polarization before treatment. $I$ elevated serum LMMFs and depressed monocyte polarization; $I I$ elevated serum LMMFs and normal monocyte polarization; III non-elevated serum LMMFs and depressed monocyte polarization; $I V$ non-elevated serum LMMFs and normal monocyte polarization ( patients, $O$ healthy controls)

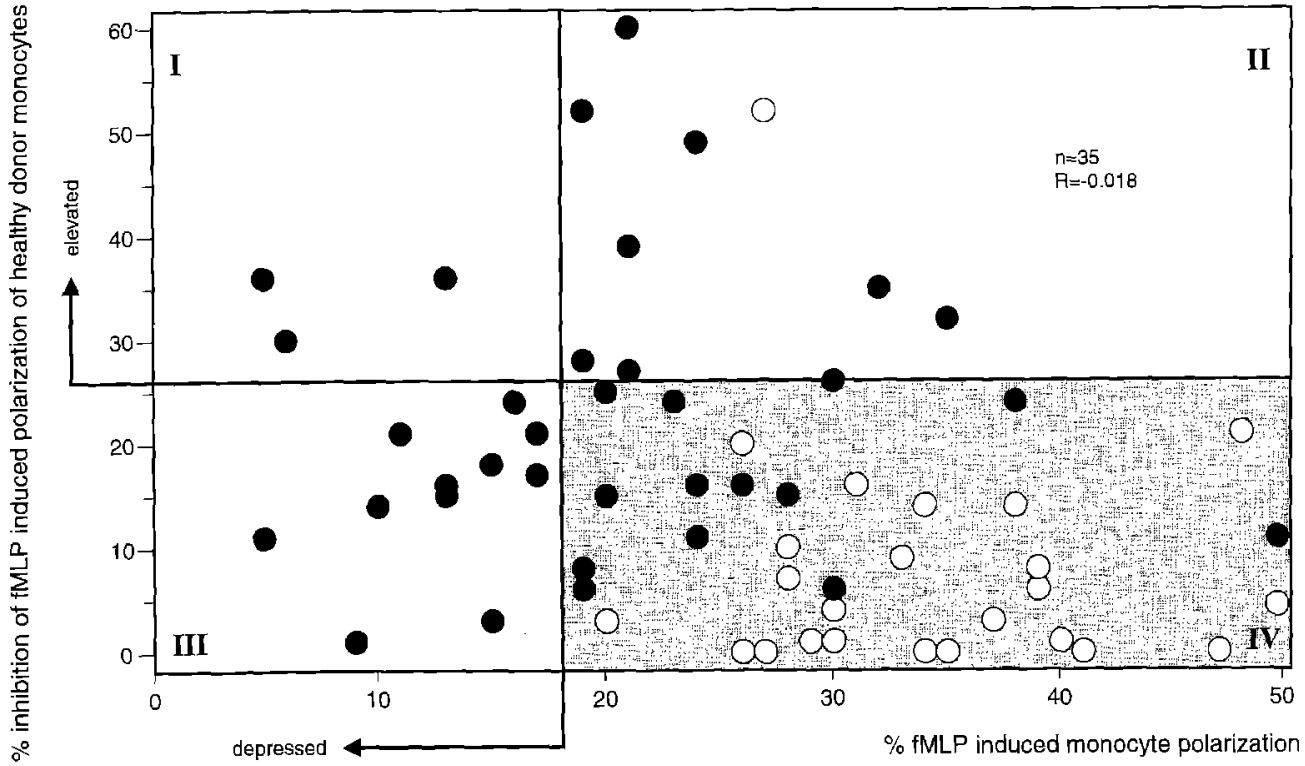

\section{Results}

Defects of monocyte polarization and dendritic cell clustering capability in relation to serum p15E-like LMMF levels

Figure 1 shows pretreatment levels of p15E-like LMMFs in the sera of individual HNSCC patients in comparison to their individual monocyte chemotactic capabilities. Levels of p15E-like LMMFs in patient sera were determined indirectly by measuring their suppressive effects on fMLP-induced monocyte polarization of healthy blood donors.

In the control group of healthy volunteers the mean monocyte polarization was $34.2 \% \pm 7.9(n=23)$, while the mean bioactive inhibitory level of p15E-like LMMFs was $7.3 \% \pm 9.3(n=23)$. Monocyte polarization $<18.4 \%$ (mean $-2 \mathrm{SD}$ ) was therefore considered to be defective, and LMMF levels $>25.9 \%$ inhibition (mean $+2 \mathrm{SD}$ ) were considered elevated. According to these criteria, 16 patients $(40 \%)$ had defective monocyte polarization, viz chemotaxis of lower than $18.4 \%$ towards the chemoattractant fMLP prior to treatment. Twelve patients $(31 \%)$ had elevated p15E-like LMMF levels. The patients with defective monocyte chemotaxis were evenly distributed over the group that had normal serum LMMF levels and the group that had elevated serum LMMF levels, and no correlation was possible between elevated LMMF levels and disturbed monocyte chemotactic capability $(n=35, r=$ $0.018, P>0.1$ ).

The mean dendritic cell cluster assay in the healthy controls was $133.5 \pm 42$ clusters $/ 6$ microscopic fields $(n=$ 17). A value of less than 92 clusters $/ 6$ microscopic fields (mean - 1 SD) was considered to be abnormal. According to this criterion 16 patients had defective dendritic cell clustering capability before treatment. A correlation between dendritic cell clustering capability and p15E-like
LMMF levels could not be detected $(n=34, r=-0.10, P>$ 0.5 ). Furthermore no correlation existed between dendritic cell clustering capability and monocyte polarization $(n=$ $34, r=0.08, P>0.5$ ).

Effects of TP1 treatment on monocyte polarization, dendritic cell clustering capability and serum p15E-like LMMF levels

Figure $2 \mathrm{a}$ shows fMLP-induced polarization of monocytes isolated from the blood of HNSSC patients before surgery (day 0 ) and 10 days after surgery (day 10 ) and administration of either placebo or a TP1 dosage. In all four groups the mean initial value (day 0 ) was markedly lower than the $34.2 \%$ mean of the polarized monocytes found in the healthy control group.

Treatment with $1.0 \mathrm{mg} / \mathrm{kg}$ TP1 resulted in a restoration of disturbed monocyte polarization from $17.6 \% \pm 6.3(n=$ 13) to a near-normal value of $30.9 \% \pm 13.8(n=13)$ at day $10(P<0.01)$. Similar effects were seen with $2.0 \mathrm{mg} / \mathrm{kg}$ TP1 $(P<0.05)$. Monocyte polarization improved to $32.0 \% \pm 15.8(n=9)$ from an initial $17.8 \% \pm 18.2(n=9)$. Treatment with $0.5 \mathrm{mg} / \mathrm{kg}$ TP1 showed no significant improvement $(20.9 \% \pm 7.0$ to $23.0 \% \pm 8.1, n=10)$. Placebo treatment also showed no significant effect on the impaired monocyte polarization $(24.0 \% \pm 14.2$ to $25.7 \% \pm$ $8.3, n=9)$.

Figure $2 b$ shows the number of clusters formed by monocyte-derived dendritic cells from the sera of HNSSC patients. At day 0, patients of all four groups showed lower values than normal, although this was least marked for the placebo group. All three TP1-treated groups showed an increase in mean dendritic cell clustering capability after treatment $(0.5 \mathrm{mg} / \mathrm{kg}$ group: $86.0 \pm 37.0$ to $121.1 \pm 38.2, n=9 ; 1.0 \mathrm{mg} / \mathrm{kg}$ group: $99.7 \pm 34.2$ to 116.6 $\pm 23.0, n=11 ; 2.0 \mathrm{mg} / \mathrm{kg}$ group: $98.4 \pm 30.5$ to $113.3 \pm$ $23.0, n=9$ ). However, only the change in the $0.5 \mathrm{mg} / \mathrm{kg}$ 
Fig. 2a Percentage of formylmethionylleucylphenylalanine (fMLP)-induced monocyte polarization before and after 10 days of TP1 treatment $(\diamond$ placebo, $\bigcirc 0.5 \mathrm{mg} / \mathrm{kg} \mathrm{TP1}$, $\square 1.0 \mathrm{mg} / \mathrm{kg} \mathrm{TP} 1, \triangle 2.0$ $\mathrm{mg} / \mathrm{kg}$ TP1). b Number of dendritic cell-lymphocyte clusters per 6 microscopic fields $(\times 200)$ obtained with dendritic cells from patient sera before and after 10 days of TP1 treatment. ( $>$ placebo, $\bigcirc 0.5$ $\mathrm{mg} / \mathrm{kg}$ TP1, $\square 1.0 \mathrm{mg} / \mathrm{kg}$ TP1, $\triangle 2.0 \mathrm{mg} / \mathrm{kg}$ TP1). c Percentage inhibition of fMLP-induced polarization of healthy donor monocytes by LMMFs prepared from patients before and after 10 days of TP1 treatment $(\diamond$ placebo, $\bigcirc 0.5 \mathrm{mg}$ ) $\mathrm{kg} \mathrm{TP} 1, \square 1.0 \mathrm{mg} / \mathrm{kg} \mathrm{TP} 1$, $\triangle 2.0 \mathrm{mg} / \mathrm{kg} \mathrm{TPI})$
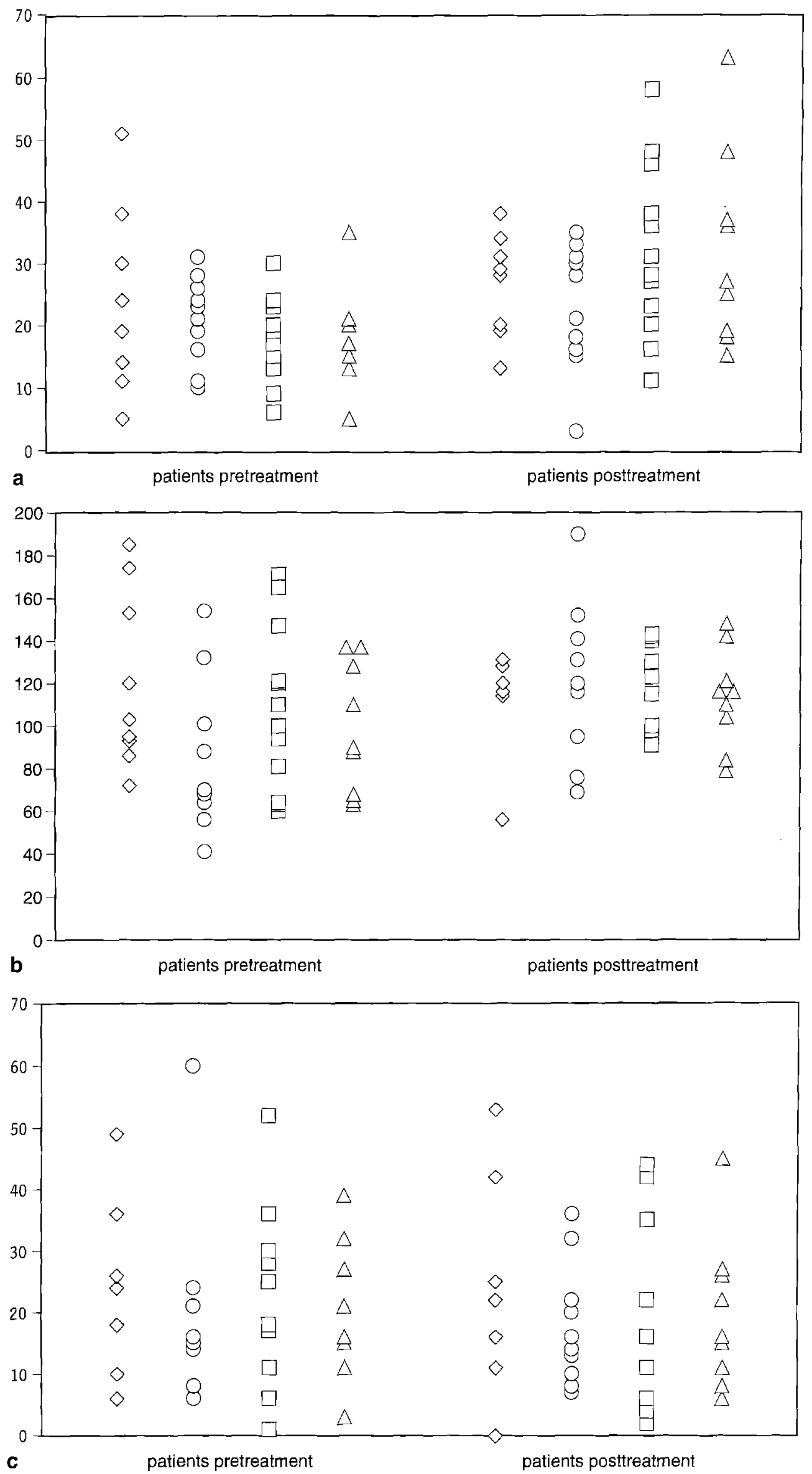
group reached statistical significance $(P<0.05)$. The placebo group showed some decrease in the clustering capability of dendritic cells, but this decrease was not statistically significant.

Pretreatment levels of p15E-like LMMFs and values found after 10 days of TP1 treatment are shown in Fig. 2c. No significant changes were found in the levels of serum p15E-like factors in group I $(0.5 \mathrm{mg} / \mathrm{kg}, n=7)$, group II (1.0 $\mathrm{mg} / \mathrm{kg}, n=15)$, group III $(2.0 \mathrm{mg} / \mathrm{kg}, n=9)$ or placebo $(n=9)$.

\section{Discussion}

Suppression of cell-mediated immunity in HNSCC is thought to be at least partially due to immunosuppressive LMMFs produced and released by tumors [9]. These factors show a structural homology to retroviral protein p15E. The p15E-like LMMFs and a 17-amino-acid peptide synthesized from MuLV p15E (anti-CKS-17) exert a suppressive effect on various immune cells. Suppression has been demonstrated in vitro on monocyte chemotactic responses [9, 36]; monocyte cytotoxicity by inactivating interleukin-1 (IL-1) $[15,22]$; the respiratory burst of human monocytes [17]; activation of feline neutrophils [23]; IL-2- or IL-1-dependent proliferations of T-cells and their blastogenic responses to mitogens and allo-antigens [11, 30,33 , activity of human natural killer (NK) cells [18]; polyclonal activation of B-cells [27] and the capability of dendritic cells to form clusters per se and with T-cells [32, 41].

The presence of immunosuppressive p15E-like factors can be detected in the serum of HNSCC patients via a bioassay using healthy donor monocytes. In previous studies we showed that removal of a tumor often resulted in a postoperative decline of the level of these serum p15E-like LMMFs [42], and restoration of monocyte chemotactic responsiveness [36]. We assumed that there was a direct effect on monocyte chemotaxis by immunosuppressive p15E-like LMMFs produced by tumor and circulating in serum, since direct contact between monocytes and the serum p15E-like factors seemed inevitable. Our present data, however, have failed to demonstrate any positive correlations between defective monocyte chemotaxis or dendritic cell clustering and serum levels of $\mathrm{p} 15 \mathrm{E}-$ like LMMFs.

An explanation for our present findings may be due to heterogeneity in sensitivity of monocytes of individual HNSCC patients to immunosuppressive effects of $\mathrm{p} 15 \mathrm{E}-$ like factors. It is also possible that other immunomodulating factors produced in our patients and stimulating or suppressing monocyte chemotaxis may play an additional role. A third explanation might be that defective monocyte polarization and dendritic cell clustering might not be a direct result of elevated p15E-like LMMFs in serum, but that these immunosuppressive factors could possibly exert such effects as hampered maturation of fully active monocytes and dendritic cells at the level of the bone marrow. In contrast, healthy individuals may have relatively high serum levels of p15E-like LMMFs without showing clinical or experimental signs of immune suppression [39].

Our results do show restoration of defective monocyte chemotactic responsiveness in HNSCC patients due to treatment with TP1. Treatment with $1.0 \mathrm{mg} / \mathrm{kg}$ or 2.0 $\mathrm{mg} / \mathrm{kg}$ body weight administered intramuscularly for 10 consecutive days prior to operation has given near-normal values for monocyte responsiveness on the day of operation. Statistically, $1.0 \mathrm{mg} / \mathrm{kg}$ was found to be the most optimal dose for restoration of the monocyte polarization, which has also been reported to be the dose most frequently used to treat patients with various other disorders $[1,7,40]$. An improvement of the dendritic cell clustering capability after TP1 treatment was seen for all TP1treated groups; however only in the $0.5 \mathrm{mg} / \mathrm{kg}$ group did this reach statistical significance. A plausible explanation for this may be that the mean pretreatment values of the dendritic cell cluster assay of the $1.0 \mathrm{mg} / \mathrm{kg}$ and $2.0 \mathrm{mg} / \mathrm{kg}$ groups were less disturbed than those of the $0.5 \mathrm{mg} / \mathrm{kg}$ group. Therefore the possible improvement that could be achieved was less pronounced. Tas et al. [40] treated patients with chronic purulent rhinosinusitis and found a similar restorative effect of TP1 treatment on monocyte chemotactic functions accompanied by a concomitant decrease in serum p15E-like LMMF levels as well as clear clinical improvement.

In our current study, p15E-like LMMF levels in sera from HNSCC patients were unaffected by TP1 treatment. These findings suggest that TP1 counteracts the immunosuppressive effects of p15E-like factors at a cellular level and TP1 does not affect production of p15E-like factors by tumor. The decrease in detectable serum LMMF levels reported in patients with rhinosinusitis after TP1 treatment could also be explained by a lower production due to improved clinical status, rather than a direct effect of TP1 on the production or immunosuppressive properties of these p15E-like LMMFs. Conclusions concerning clinical effects of TP1 in the treatment of HNSCC cannot be drawn from our study at this time and will be addressed in a later report on the long-term results of TP1 treatment.

Acknowledgements The authors would like to thank Dr. P. P. Knegt, Dr. G. J. Gerritsen, Dr. N. de Vries, Dr. P. Delaere and Dr. I. B. Tan for their efforts and participation in this study. p15E-specific monoclonal antibodies (mAbs 4F5 and 19F8) were kindly provided by Dr. G. J. Cianciolo, Genentech Inc. Pharmacological Sciences, San Francisco, California, USA

\section{References}

1. Aiuti F, Sirianni MC, Fiorilli M, Paganeli R, Stella A, Turbessit G (1984) A placebo-controlled trial of thymic hormone treatment of recurrent herpes simplex labialis infection in immunodeficient host: results after a 1-year follow-up. Clin Immunol Immunopathol 30:11-18

2. Austyn JM, Weinstein DE, Steinman RM (1987) Clustering with dendritic cells precedes and is essential for T-cell proliferation in a mitogenesis model. Immunology $63: 691-696$ 
3. Balm AJM, Drexhage HA, Von Blomberg ME, Snow GB (1982) Mononuclear phagocyte function in head and neck cancer: NBT-DYE reduction, maturation and migration of peripheral blood monocytes. Laryngoscope 92:810-814

4. Balm AJM, Von Blomberg-Van de Flier BME, Drexhage HA, Haan-Meulman M de, Snow GB (1984) Mononuclear phagocyte function in head and neck cancer: depression of murine macrophage accumulation by low molecular weight factors derived from head and neck carcinomas. Laryngoscopy $94: 223-$ 227

5. Balm AJM, Drexhage HA, Von Blomberg M, Weltevreden EF, Veldhuizen RW, Mullink R, Snow GB (1984) Mononuclear phagocyte function in head and neck cancer: chemotactic responsiveness of blood monocytes in correlation between histologic grade of the tumor and infiltration of these cells into the tumor area. Cancer $54: 1010-1015$

6. Bergesi G, Falchetti $R$ (1977) Chemical characterization and biological activity of a new thymic extract. Folia Allergol Immunol Clin $21: 204-208$

7. Bernengo MG, Fra P, Lisa F, Meregalli M, Zina G (1983) Thymostimulin therapy in melanoma patients: correlation of immunologic effects with clinical course. Clin Immunol Immunopathol $28: 311-324$

8. Cameron DJ, Stromberg BV (1984) The ability of macrophages from head and neck cancer patients to kill tumor cells. Cancer 54:2403-2408

9. Cianciolo GJ (1986) Antiinflammatory proteins associated with human and murine neoplasms. Biochem Biophys Acta $865: 69-82$

10. Cianciolo GJ, Snyderman R (1981) Monocyte responsiveness to chemotactic stimuli is a property of a subpopulation of cell than can respond to multiple chemoattractants. J Clin Invest 67 : $60-68$

11. Cianciolo GJ, Copeland TD, Oroszlan S, Snyderman R (1985) Inhibition of Iymphocyte proliferation by a synthetic peptide homologous to retroviral envelope proteins. Science 230:453455

12. Falchetti R, Bergesi G, Eshkol A, Cafiero C, Adorini L, Caprino L (1977) Pharmacological and biological properties of a calf thymus extract (TP1). Drugs Exp Clin Res 3:39-47

13. Fossum S (1988) Lymph-borne dendritic leucocytes do not recirculate, but enter the lymph node paracortex to become interdigitating cells. Scand J Immunol $27: 97-105$

14. Garraud O, Faucher A, Legrand E (1988) Impairment of monocyte functions in advanced head and neck cancer. Immunol Lett $18: 213-218$

15. Gottlieb RA, Lennarz WJ, Knowles RD, Cianciolo GJ, Dinarello CA, Lachman LB, Kleinerman ES (1989) Synthetic peptide corresponding to a conserved domain of the retroviral protein p15E blocks IL-1-mediated signal transduction. J Immunol 142:4321-4328

16. Güngör A, Yetgin S, Sözeri B (1993) Defective monocyte chemotaxis in patients with epidermoid tumors of the head and neck. Eur Arch Otorhinolaryngol 250:289-291

17. Harrell RA, Cianciolo GJ, Copeland TD, Oroszlan S, Snyderman R (1986) Suppression of the respiratory burst of human monocytes by a synthetic peptide homologous to envelope proteins of human and animal retroviruses. J Immunol 136:35173519

18. Harris DT, Cianciolo GJ, Snyderman R, Argov S, Koren HS (1987) Inhibition of human natural killer cell activity by a synthetic peptide homologous to a conserved region in the retroviral protein, p15E. J Immunol 138:889-894

19. Inaba K, Steinman RM (1987) Monoclonal antibodies to LFA1 and CD4 inhibit the mixed leukocyte reaction after the antigen-dependent clustering of dendritic cells and $T$ lymphocytes J Exp Med 165: 1403-1417

20. Jenkins VK, Ray P, Ellis HN, Griffiths CM, Perry RR, Olson MH (1976) Lymphocyte response in patients with head and neck cancer. Arch Otolaryngol 102:596-600
21. Kabel PJ, Haan-Meulman M de, Voorbij HAM, Kleingeld M, Knol EF, Drexhage HA (1989) Accessory cells with a morphology and marker paterns of dendritic cells can be obtained from elutriator-purified blood monocyte fractions. An enhancing effect of metrizamide in this differentiation. Immunobiology 179:395-411

22. Kleinerman ES, Lachman LW, Knowles RD, Snyderman R, Cianciolo GJ (1987) A synthetic peptide homologous to the envelope proteins of retroviruses inhibits monocyte-mediated killing by inactivating interleukin 1. J Immunol 139:2329-2337

23. Lafrado LJ, Lewis MG, Mathes LE, Olsen RG (1987) Suppression of in vitro neutrophil function by Feline Leukaemia Virus (FeLV) and purified FeLV-p15E. J Gen Virol 68:507-513

24. Lapointe H, Lampe H, Banerjee D (1992) Head and neck squamous cell carcinoma cell line-induced suppression of in vitro lymphocyte proliferative responses. Otolaryngol Head Neck Surg 106:149-158

25. Liberati AM, Ballatori E, Fizzotti M, Schippa M, Cini L, Cinieri S, Proietti MG, Di Marzio R, Senatore M, Grignani F (1988) A randomized trial to evaluate the immunorestorative properties of thymostimulin in patients with Hodgkin's disease in complete remission. Cancer Immunol Immunother 26:8793

26. Mignot MH, Lens JW, Mullink H, Stolk JG, Oort J, Drexhage $\mathrm{HA}(1985)$ The involvement of dendritic cells in the handling of the immune stimulant C. parvum. Virchows Arch [B] 48: 317-324

27. Mitani M, Cianciolo GJ, Snyderman R, Yasuda M, Good RA, Day NK (1987) Suppressive effect on polyclonal B-cell activation of a synthetic peptide homologous to a transmembrane component of oncogenic retroviruses. Proc Natl Acad Sci USA $84: 237-240$

28. Mooy P, Simons PJ, Haan-Meulman M de, Wit HJ de, Drexhage HA (1994) Effect of thyroid hormones and other iodinated compounds on the transition of monocytes into veiled/dendritic cells: role of granulocyte-mactophage colonystimulating factor, tumour-necrosis facter- $\alpha$ and interleukin- 6 . J Endocrinol 140:503-508

29. Mullink H, Von Blomberg-van der Flier M, Wilders MM, Drexhage HA, Alons CL (1979) A simple cytochemical method for distinguishing EAC rosettes formed by Iymphocytes and monocytes on density gradients of Percoll. J Immunol Methods $33: 133-137$

30. Orosz CG, Zinn NE, Olsen RG, Mathes LE (1985) Retrovirusmediated immunosuppression. I. FeLV-UV and specific FeLV proteins alter $\mathrm{T}$ Iymphocyte behaviour by inducing hyporesponsiveness to lymphokines. J Immunol 134:3396-3404

31. Pertoft H, Johnsson A, Wärmegärd B, Seljelid R (1980) Separation of human monocytes on density gradients of Percoll. J Immunol Methods 33:221-229

32. Scheeren RA (1992) Chronic upper airway infections. The role of pl5E-like proteins and defect in cell-mediated immunity. Thesis, chapter 5, Free University Amsterdam

33. Schmidt DM, Sidhu NK, Cianciolo GJ, Snyderman R (1987) Recombinant hydrophilic region of murine retroviral protein p15E inhibits stimulated T-lymphocyte proliferation. Proc Natl Acad Sci USA 84: 7290-7294.

34. Setti M, Balleari E, Indiveri F (1994) Pathophysiological bases and approach to clinical use of thymic hormones. Semin Clin Immunol 7:47-64

35. Steinman RM (1991) The dendritic cell system and its role in immunogenicity. Annu Rev Immunol 9:271-296

36. Tan IB (1986) Retroviral p $15 E$ related factors in head and neck cancer. Thesis, Vonk/Zeist, The Netherlands

37. Tan IB, Drexhage HA, Scheper RJ, Von Blomberg-van der Flier BM, Haan-Meulman M de, Snow GB, Balm AJM (1986) Defective monocyte chemotaxis in patients with head and neck cancer. Arch Otolaryngol Head Neck Surg 112:541-544 
38. Tan IB, Drexhage HA, Scheper RJ, Von Blomberg-van der Flier BM, Haan-Meulman M de, Snow GB, Balm AJM (1986) Immunosuppressive retroviral p15E-related factors in head and neck carcinomas. Arch Otolaryngol Head Neck Surg 112:942945

39. Tas M (1992) Immunosuppression by retrovirus-related factors. Restoration of p15E-like effects by thymic hormones. Thesis, chapter 8, Erasmus University Rotterdam

40. Tas M, Leezenberg JA, Drexhage HA (1990) Beneficial effects of the thymic hormone preparation thymostimulin in patients with defects in cell-mediated immunity and chronic purulent rhinosinusitis. A double-blind cross-over trial on improvements in monocyte polarization and clinical effects. Clin Exp Immunol 80:304-314

41. Tas M, Haan-Meulman M de, Kabel PJ, Drexhage HA (1991) Defects in monocyte polarization and dendritic cell clustering in patients with Graves' disease. A putative role for a nonspecific immunoregulatory factor related to p15E. Clin Endocrinol $34: 441-448$
42. Tas M, Laarman D, Haan-Meulman M de, Balm AJM, Snow GB, Drexhage HA (1993) Retroviral p15E-related serum factors and recurrence of head and neck cancer. Clin Otolaryngol $18: 324-327$

43. Tas MP, Simons PJ, Balm AJM, Drexhage HA (1993) Depressed monocyte polarization and clustering of dendritic cells in patients with head and neck cancer: in vitro restoration of this immunosuppression by thymic hormones. Cancer Immunol Immunother 36:108-114

44. Vlock DR (1991) Immunobiologic aspects of head and neck cancer. Hematol Oncol Clin North Am 5: 797-820

45. Walter RJ, Danielson JR (1987) Characterization of formylpeptide chemoattractant binding on neutrophils and monocytes from patients with head and neck cancer. J Natl Cancer Inst 78 : $61-67$ 